\title{
The Application Analysis of Computer Network Teaching in College PE Appreciation Course
}

\author{
$\operatorname{Min} \mathrm{Li}^{1, \mathrm{a}}$ \\ ${ }^{1}$ Jiangxi Science and Technology Normal University, Nanchang, Jiangxi, 330013, China
}

\begin{abstract}
Keywords: Colleges and Universities; Sports Appreciation Classes; Computer Networks; Teaching
\end{abstract} Models

\begin{abstract}
With the development and popularization of computer technology, Chinese education field ushered in a new educational model, including computer network teaching is one of the most popular models. At present, the use of computer networks to show college appreciation sports is a very suitable form of teaching, with a very strong practical and imitation. Therefore, based on the current mature campus network, with the Internet knowledge, computer knowledge, multimedia knowledge, modern communication knowledge to develop students' physical exercise ability and promote the formation of physical awareness for students and provide a wealth of sports learning projects, increase the students' ability of autonomous physical education, and further develop a more valuable learning area for sports learners and enthusiasts.
\end{abstract}

\section{Introduction}

At present, all areas of society have developed and applied the advanced technology of computer network. With the improvement of Internet technology application level, "computer network teaching" has been gradually applied to teaching by the major universities and the Ministry of Education. Among them, the use of computer network to learn college sports appreciation classes came into being, set the computer network technology, improve students' sports appreciation ability, cultivate sports talents, improve the quality of physical education in one, has a significant impact on the field of education. The application of computer network in sports teaching is a good starting point for the realization of physical education. Sports computer network teaching will also become an important step towards the future of sports. The reform and development of physical education make college physical education into a new era of knowledge and network coexistence. The quality of college students' sports has become an important weight of national comprehensive national strength and competitiveness in the whole world. How to use the computer network in the sports appreciation of the application is a worthy of research projects.

\section{The Analysis of the Significance of College Physical Education Appreciation Course in Computer Network Teaching}

Through the Internet to learn knowledge is one of the necessary means of modern education development, is the inevitable result of the times and social development. The traditional mode of physical education has been in students' passive acceptance of boring sports and exercise, and by means of computer network teaching is through the expression of the characters and the image of the sports activities to vividly infected students, to stimulate students to consciously learn sports Items and exercise. In appreciation and enjoy the beauty of sports at the same time, more love of physical exercise, thereby enhancing the physical fitness. Compared with the tedious and non-interactive teachers, the rational use of computer network for college sports appreciation class is more popular with the students and praise.

The teaching of sports appreciation plays a key role in cultivating college students' lifelong physical exercise. Lifelong physical exercise requires students to love the absolute love, absolute self-discipline and absolute participation in order to get a healthy and strong physical fitness. Cultivate and establish this sense of lifelong exercise and college sports education program set up, college students like sports, understand the benefits of sports, enjoy the sports picture, enjoy the 
process of sports is the sports appreciation of the teaching objectives. So that college students in the sports appreciation of the class was attracted by its innovative form, have a strong interest, love, choose their favorite way to exercise the body and work to solve the life and learning pressure, tempered their own will and faith has a very good effect.

\section{The Application of College Sports Appreciation Courses in Computer Network Teaching}

College sports teacher there dogmatism, did not really pay attention to the importance of sports appreciation teaching. In physical education, some sports teachers and students rigid, computer network teaching level is limited, limited to the physical habits of sports courses on some traditional sports. This has led to the lack of problems in the lack of sports resources, making the physical education venues and venues, equipment and equipment problems become increasingly prominent, deepening the quality of physical education and the completion of the contradiction between the goals of physical education teaching.

The computer network and multimedia teaching venues and equipment management is not comprehensive. In the case of bad weather, school sports appreciation classes can be useful. In addition, many college sports appreciation classes are classified as elective courses, to give students the feeling of dispensable [1]. It is assigned to the school class collective, the University of the Office of Academic Affairs cannot be arranged according to the curriculum to sufficient multimedia classrooms to students, so the sports appreciation of the students in the hearts of students cannot afford a negative attitude.

Optimize the teaching of sports appreciation teaching resources and computer network teaching standardization. Computer Internet in the sports information resources are numerous and complex, so the requirements of sports teachers choose to arrange some scientific inquiry significance of teaching resources content shown in college students in the teaching of sports appreciation classes. Do not meet the physical education teaching objectives, can not reflect the technical and tactical level of teaching content does not advocate to bring college students, but to promote the use of people to bring the feelings and philosophical thinking of teaching and computer network resources.

\section{The Method to Improve the Computer Network Information Resources for College Sports Appreciation Course}

We must improve the computer education resources in college sports appreciation of the degree of attention. Sports appreciation class in the computer network to obtain a very large amount of material resources, has a rich content and form, showing the complexity of information and diversity characteristics. In the teaching of sports appreciation of teaching materials, to scientific and rational choice for sports appreciation course teaching information resources. Sports appreciation classes should be clear with the integration of computer resources, the rationalization of computer information resources and standardization of the building [2]. The use of multimedia teaching to cultivate college students 'interest in sports learning, and to broaden the students' sports knowledge, to help schools effectively alleviate the lack of difficulties in sports content. Therefore, the construction of college sports quality education needs the computer network of sports appreciation course, in the future of college physical education and sports lifelong teaching project, increase the computer network teaching, convenience, active learning, adaptability and other advantages.

College sports appreciation classes require lecturers pro-grant and college students earnestly complement each other. With the application and popularization of computer Internet, the sports in the syllabus have added many new projects. College students are interested in the popular, contested and popular sports. The function of computer network teaching in sports appreciation course is to enhance the ability of college students to respect sports beauty through the network teaching of sports appreciation course. In order to meet the various requirements of college students' teaching of sports appreciation, the use of computer network teaching in sports appreciation course is recommended to students, and college students may be attracted by the sports charm of sports. 
Learning sports skills and adhere to the interest in physical exercise, to participate in physical exercise have a better vision, so as to achieve the voluntary self-conscious students to participate in the purpose of physical exercise. On the other hand, the lectures of the lecturers in colleges and universities must play a role in the appreciation of college students' sports, and take the initiative to lead the students to dig the beauty of sports action, from which the beauty of the masculine beauty and soft beauty. College sports teaching course computer network teaching not only college students are enthusiastic about sports learning, but also increase the sports lecturer in the students with the interaction, pleasure, vivid sense.

College sports appreciation course computer network teaching practice. The goal of college sports appreciation course is to cultivate the consciousness of college students' lifelong exercise and healthy physical quality, and have the interesting and interest of contemporary young people to appreciate sports beauty. In the college sports appreciation course to understand why to learn sports and how to learn sports [3]. Only to break through the traditional constraints, in order to re-examine the benefits of sports to bring people to create more and better sports activities. For example, in the central 5 sets of broadcast the US men's basketball live broadcast, you can refer to college students to observe and appreciate. College students in the teaching process can see the wonderful scene of the men's basketball team and you can also see their worship of the men's basketball idol, but also to understand the background of basketball stars, but also to watch the basketball game cheerleaders graceful dance. In the sports appreciation of the computer network teaching, from the perspective of sports to teach, so that college students understand the sport's dynamic, sense of force, beauty, charm, so that college students with a favorite look to see the charm of sports and magic so as to achieve college students appreciate sports, love sports, adhere to sports, looking forward to the purpose of sports teaching requirements.

\section{Conclusion}

The sports appreciation course computer network teaching has a certain guiding role to help college students to consciously carry out physical exercise. The effective use of college sports resources and teaching software can promote the guidance of some colleges and universities in sports appreciation and the exploration of PE teaching leader. The use of the function of computer network teaching in the college sports appreciation in the contemporary university education has a lot of space to develop and optimize the physical education model to advance the road, it is conducive to the deepening of physical education reform, to cultivate students physical exercise ability and it has a more significant role in promoting lifelong physical exercise habits.

\section{References}

[1] Guo Xiaowen. Study on the Autonomous Learning of PE Majors Based on Network Environment [J]; Journal of Fujian Normal University (Philosophy and Social Sciences Edition), 2015

[2] Hong Xiaoxiao. Internet age college students sports life status survey [D]. Shandong University, 2014

[3] Wang Ning, Liu Chuanqin. Talking about the development of network technology in college physical education[J]. Contemporary Sports Science and Technology, 2012, (32): 38 - 40. 